\title{
Comparing the outcome of patients discharged in early postoperative period, with patients discharged at late postoperative period in a tertiary care hospital
}

\author{
Kavitha Marimuthu*, Malarvizhi Loganathan
}

Department of Obstetrics and Gynecology, Government Dharmapuri Medical College, Dharmapuri, Tamil Nadu, India

Received: 05 May 2017

Accepted: 29 May 2017

*Correspondence:

Dr. Kavitha Marimuthu,

E-mail:draksn@gmail.com

Copyright: (c) the author(s), publisher and licensee Medip Academy. This is an open-access article distributed under the terms of the Creative Commons Attribution Non-Commercial License, which permits unrestricted non-commercial use, distribution, and reproduction in any medium, provided the original work is properly cited.

\begin{abstract}
Background: It has become common practice to discharge women from hospital early after caesarean section, to satisfy their wishes or to reduce workload the objectives of this study were to determine women's satisfaction, and rates of wound infection, maternal readmission, and early postnatal depression. Postnatal hospital stay has two main objectives; the first, to identify any complication for both mother and newborn and the second, to provide the necessary support to the new mother for her return home. The two main reasons for this change in the service provided are to improve women's satisfaction during this period and to reduce the cost to the health system.

Methods: Retrospective study from January 2016 to January 2017 in a tertiary care hospital. Patient underwent Lower Section Caesarean Section (LSCS) were grouped into 2 groups. Group I- patients discharged on $5^{\text {th }}$ postoperative day (POD). Group II-patient discharged at $8^{\text {th }}$ POD. 500 patients were included in each group. Patient discharged on $5^{\text {th }}$ POD was instructed about the warning symptoms of puerperium about fever, breast engorgement, wound discharge, foul smelling vaginal discharge, and advised for suture removal in nearby health facility.

Results: Those who discharged at $5^{\text {th }}$ POD (500) were followed through phone at 10th POD and only 498 could be traced and complications and satisfaction was made in discharge proforma. Of 500 patients discharge at 5th POD only 498 responded to phone call. Wound infection was found in 2 patients of those 2 , both were asked to attend the postnatal clinic and found to have mild wound induration with minimal wound discharge which responded well to oral anti biotic and daily dressing in nearby health facility.

Conclusions: In developing countries like India $70 \%$ of the patients undergo delivery in government hospitals. Most of them were belong to low socio-economic status and they have to go to daily work for their daily needs. If a patient is admitted for a prolonged period in a hospital the helping members who come to hospital, have to stay along with the patients and they will lose their daily income which will create debt to the family which in turn causes economic burden and psychological stress. This will reflect on the post-natal nutrition to the mother and baby.
\end{abstract}

Keywords: Complications, Early discharge, Economical burden, Late discharge, Post cesarean, Satisfaction

\section{INTRODUCTION}

It has become common practice to discharge women from hospital early after caesarean section, to satisfy their wishes or to reduce workload. The objectives of this study were to determine women's satisfaction, and rates of wound infection, maternal readmission. Postnatal hospital stay has two main objectives; the first, to identify any complication for both mother and newborn and the second, to provide the necessary support to the new mother for her return home. ${ }^{1}$ During the last 60 years there has been a worldwide tendency to reduce the length of time women stay in the hospital after giving birth. In 1992, the American Academy of Pediatrics and the 
American College of Obstetricians and Gynecologists defined early postnatal discharge (ED) as a stay of less than $48 \mathrm{hrs}$ for women who had vaginal deliveries and less than 96hrs those who had cesarean sections. ${ }^{2}$ The two main reasons for this change in the service provided are to improve women's satisfaction during this period and to reduce the cost to the health system. ${ }^{3}$

Despite the efforts of several researchers around the world systematically assessing and evaluating the effects of this new service on women and newborns, there is still uncertainty about what the pros and cons of the shorter hospital postnatal stay are. In the context of a pioneer Chilean project which aims to develop an innovative modality of childbirth, including a reduction in the length of postnatal stay, we aimed to review the literature available and to examine the advantages and disadvantages of early postnatal discharge for both the healthy mother and child and the consequent repercussions for the health system which should be considered when proposing a reduction in the length of stay after childbirth. ${ }^{4}$

The aim of the study was to compare the outcome of postoperative patients discharged in early postoperative period, with patients discharged at late postoperative period in a tertiary care hospital. To reduce the duration of hospital, stay. To reduce the incidence of hospital acquired infection for both mother and baby. To reduce the problems regarding availability of patients' bed strength. To reduce the expenditure for government towards patients. To avoid mental stress for patient's family.

\section{METHODS}

Retrospective study from January 2016 to January 2017 in a tertiary care hospital. Patient underwent Lower Section Caesarean Section (LSCS) were grouped into 2 groups. Group I- patients discharged on $5^{\text {th }}$ post-operative day (POD). Group II-patient discharged at $8^{\text {th }}$ POD. 500 patients were included in each group. Patient discharged on $5^{\text {th }}$ POD was instructed about the warning symptoms of puerperium about fever, breast engorgement, wound discharge, foul smelling vaginal discharge, and advised for suture removal in nearby health facility. Those patients discharged on $5^{\text {th }}$ POD was enquired through phone about the wound infection, fever, Respiratory tract infection, post-partum hemorrhage, and other complications. The patient was contacted over phone at $10^{\text {th }}$ POD and enquired about the problems faced /Satisfaction and entries made in the discharge proforma. Patients staying till $8^{\text {th }}$ POD were followed for the same complications in the hospital.

\section{Inclusion criteria}

P1L1, P2L2, age <25 years, no underlying medical disorder, no risk of wound infection, Willing to go at $5^{\text {th }}$ POD. $\mathrm{Hb}>9 \mathrm{gms} \%$.

\section{Exclusion criteria}

Multigravida, Complicated with indication like anemia, Diabetes, PIH, thromboembolism (TE). Wound infection/ indication and Not willing to go at $5^{\text {th }}$ POD.

\section{RESULTS}

Those who discharged at $5^{\text {th }}$ POD (500) were followed through phone at $10^{\text {th }}$ POD and only 498 could be traced and complications and satisfaction was made in discharge proforma.

Of 500 patients discharge at 5th POD only 498 responded to phone call. Wound infection was found in 2 patients of those 2 , both were asked to attend the post-natal clinic and found to have mild wound induration with minimal wound discharge which responded well to oral anti biotic and daily dressing in nearby health facility (Table 1).

Table 1: Complications $5^{\text {th }}$ POD.

\begin{tabular}{llllll} 
Age & $\begin{array}{l}\text { Wound } \\
\text { infection }\end{array}$ & Fever & RTI & PPH & Others \\
$\leq 25$ & 1 & 1 & 0 & - & - \\
\hline $\begin{array}{l}>25 \text { and } \\
\text { above }\end{array}$ & 1 & 1 & 2 & - & - \\
\hline
\end{tabular}

In this group 3 were found to have wound infection out of 3 patients 2 responded well to IV antibiotic and daily dressing and 1 patient undergone Re-Suturing.

The indication of caesarean for the patient who undergone the Resuturing was obstructed labour which is more prone for sepsis and wound infection (Table 2).

Table 2: Age wise complications $8^{\text {th }}$ POD.

\begin{tabular}{|llllll|}
\hline Age & $\begin{array}{l}\text { Wound } \\
\text { infection }\end{array}$ & Fever & RTI & PPH & Others \\
\hline$\leq 25$ & 2 & 1 & 1 & - & 1 \\
\hline $\begin{array}{l}>25 \text { and } \\
\text { above }\end{array}$ & 1 & - & 1 & - & - \\
\hline
\end{tabular}

In both groups, the patients had fever was mild febrile illness which responded to oral paracetomol and antibiotics. Similarly, the respiratory tract infection was found in 4 patients 2 in each group.

2 patients in study group responded for oral antibiotic and anti-histamines and cough syrup which was given in nearby health facility.

Respiratory tract infection in control group was in 2 patients both were known asthmatic hence they discharged at $10^{\text {th }}$ POD and in post-operative period they were followed with higher anti biotic and bronchodilators and nebulisation (Table 3, Table 4). 
Table 3: Gravida $5^{\text {th }}$ POD.

\begin{tabular}{|llllll|} 
Gravida & $\begin{array}{l}\text { Wound } \\
\text { infection }\end{array}$ & Fever & RTI & PPH & Others \\
\hline Primi & - & 1 & 1 & - & - \\
\hline Multi & 2 & 1 & 1 & - & - \\
\hline
\end{tabular}

Table 4: Gravida $8^{\text {th }}$ POD.

\begin{tabular}{|llllll|} 
Gravida & $\begin{array}{l}\text { Wound } \\
\text { infection }\end{array}$ & Fever & RTI & PPH & Others \\
\hline Primi & 1 & - & 1 & - & - \\
\hline Multi & 2 & 1 & 1 & - & 1 \\
\hline
\end{tabular}

Table 5: Literacy $5^{\text {th }}$ POD.

\begin{tabular}{|llllll}
\hline Literacy & $\begin{array}{l}\text { Wound } \\
\text { infection }\end{array}$ & Fever & RTI & PPH & Others \\
$\begin{array}{l}\text { Below } \\
\text { Higher }\end{array}$ & 2 & 1 & 2 & - & - \\
Sec & & & & & \\
$\begin{array}{l}\text { Above } \\
\text { Higher }\end{array}$ & - & 1 & - & - & - \\
Sec & & & & & \\
\hline
\end{tabular}

Table 6: Literacy $8^{\text {th }}$ POD.

\begin{tabular}{|llllll} 
Literacy & $\begin{array}{l}\text { Wound } \\
\text { infection }\end{array}$ & Fever & RTI & PPH & Others \\
$\begin{array}{l}\text { Below } \\
\text { Higher }\end{array}$ & 2 & - & 1 & - & \\
Sec & & & & & \\
$\begin{array}{l}\text { Above } \\
\text { Higher }\end{array}$ & 1 & 1 & 1 & - & 1 \\
Sec & & & & & \\
\hline
\end{tabular}

Of 500 patients followed in study group only 498 responded to phone and they were found to be $100 \%$ satisfied regarding early discharge which reduces their mental stress and reduces the economic burden of their family.

Though the 500 patients in control group were kept in hospital for watching complications and to treat accordingly there was no life-threatening complications observed (Figure 1, Table 7, 8).

Complications identified in the study group were also not life threatening and they responded to treatment in nearby health facility itself.

Table 7: Complications identified.

\begin{tabular}{|lll|} 
Name & $\begin{array}{l}\text { Complications } \\
\text { identified }\end{array}$ & $\begin{array}{l}\text { Patient } \\
\text { satisfaction }\end{array}$ \\
\hline $5^{\text {th }}$ POD $(n=498)$ & $6(1.2 \%)$ & $100 \%$ \\
\hline $8^{\text {th }}$ POD $(n=500)$ & $7(1.4 \%)$ & $98 \%$ \\
\hline
\end{tabular}

Table 8: Complications identified of $5^{\text {th }}$ POD and $8^{\text {th }}$ POD.

\begin{tabular}{|lll|}
\hline complications & $5^{\text {th }}$ POD discharge & $\begin{array}{l}8^{\text {th }} \text { POD } \\
\text { discharge }\end{array}$ \\
\hline Wound infection & 2 & 3 \\
\hline Fever & 2 & 1 \\
\hline RTI & 2 & 2 \\
\hline PPH & 0 & 0 \\
\hline Others & - & 1 \\
\hline
\end{tabular}

\section{DISCUSSION}

On conducting this study, there was no significant advantage in discharging the patient in the $8^{\text {th }}$ POD. Patient and their family members were satisfied if the patient is discharged in $5^{\text {th }}$ POD if there is no complication. Comparing the complications occurring in both groups there is no life-threatening complication occurs in the patient discharged in $5^{\text {th }}$ POD. Discharging the patients in early post-operative period reduces the economic burden and the hospital man power requirement.

In 1993, Strong et al indicated that women with uncomplicated pregnancies and no postoperative febrile morbidity could be discharged on postoperative day $2 .{ }^{4}$ The few reports on early discharge after cesarean birth have involved women without pregnancy complications or morbidity. ${ }^{5}$ The success of this approach of early discharge of post caesarean patients supported by decreased incidence of Re-Hospitalization and no lifethreatening complications. And if any problem arose, the availability of health facility in nearby residence with doctors and trained staff nurses ensure the safety and well-being of the mother and baby.

Hence discharging the patients without any complications like medical disorders, obesity etc. in early post-operative period is advantageous in means of reducing the cost of health care system and expenditure of the family. In developing countries like India $70 \%$ of the patients undergo delivery in government hospitals. Most of them were belong to low socio-economic status and they have to go to daily work for their daily needs. If a patient is admitted for a prolonged period in a hospital the helping members who come to hospital, have to stay along with the patients and they will lose their daily income which will create debt to the family which in turn causes economic burden and psychological stress. This will reflect on the post-natal nutrition to the mother and baby. ${ }^{5-9}$

\section{CONCLUSION}

In conclusion, discharge from hospital on the 5th postoperative day after uncomplicated caesarean section without home visits in this setting appears to be 
acceptable and safe. It is clear that telephone follow-up is an important adjunct.

Early hospital discharge holds advantages for the health care system in reducing costs only if quality outcomes are maintained. Efforts to reduce postpartum length of hospitalization may be inappropriate in terms of both quality outcomes and cost if they are based only upon data from women without complications, with short-term tracking of post-delivery complications, or no reports of subsequent health care costs or patient acceptability.

Reports now indicate that most postoperative complications in women delivered by cesarean occur after hospital discharge. These data and resulting health care costs are often difficult to capture, particularly in tertiary care centers, because referred patients may return to local physicians for care of delayed complications. Underreporting of the outcomes and costs in patients with more complicated courses and higher health care costs becomes more important in systems with capitated payment.

Approaches such as that used in this study provide a reasoned solution to maintaining quality outcomes while reducing costs. earlier hospital discharge may reduce hospital charges and return patients to their families sooner. However, some patients may be discharged too early and require rehospitalization, increased acute-care visits, and home care, which families may be unable to provide. This may be especially problematic for high-risk groups with few financial and family resources. Furthermore, complications may remain undetected or be identified late in their course.

Funding: No funding sources Conflict of interest: None declared

Ethical approval: The study was approved by the Institutional Ethics Committee

\section{REFERENCES}

1. Sainz-Bueno JA, Romano MR, Teruel RG, Benjumea AG, Palacin AF, Gonzalez CA, et al. Early discharge from obstetrics-pediatrics at the Hospital de Valme, with domiciliary follow-up. Am J Obstetr Gynecol. 2005;193(3):714-26.

2. Galbraith AA, Egerter SA, Marchi KS, Chavez G, Braveman PA. Newborn early discharge revisited: Are California newborns receiving recommended postnatal services? Pediatrics. 2003;111(2):364-71.

3. Grullon KE, Grimes DA. The safety of early postpartum discharge: a review and critique. Obstetr Gynecol. 1997;90(5):861-5.

4. Boulvain M, Perneger TV, Othenin-Girard V, Petrou $\mathrm{S}$, Berner M, Irion O. Home-based versus hospitalbased postnatal care: a randomised trial. BJOG. 2004;111(8):807-13.

5. Strong T, Brown W, Brown W, Curry C. Experience with early postcesarean hospital dismissal. Am J Obstet Gynecol. 1993;169:116-9.

6. Donahue D, Brooten D, Roncoli M, et al. Acute care visits and rehospitalizations in women and infants following cesarean birth. J Perinatol. 1994;14:36-40.

7. Schwartzberg J. Home health care and rapid rehospitalization. Home Health Care Service Q. 1982;3:25-37.

8. Jansson P. Early postpartum discharge. Am J Nurs. 1985;95:547-50.

9. Britton H, Britton J. Efficacy of early newborn discharge in a middle-class population. Am $\mathbf{J}$ Dis Child. 1984;138:1041-6.

Cite this article as: Marimuthu $\mathrm{K}$, Loganathan $\mathrm{M}$. Comparing the outcome of patients discharged in early postoperative period, with patients discharged at late postoperative period in a tertiary care hospital. Int J Reprod Contracept Obstet Gynecol 2017;6:3054-7. 